U.Ü. FEN-EDEBIYYT FAKÜLTESI

SOSYAL BILIIMLER DERGISI

Yıl: 15, Sayı: 26, 2014/1

\title{
BURSA SUR KAPILARI VE TAHT-I KALE KAPISI REKONSTRÜKSIYONU
}

İbrahim YILMAZ *

\section{ÖZET}

İlk çağlardan beri insanlar güvenliklerini sağlamak amacıyla yerleşim alanlarının etrafinı sur duvarları ile çevirmiştir. Ayrıca, yerleşim alanlarından giriş ve çıkışları sağlamak üzere de sur duvar yüzeylerinde kapılar açmışlardır. Bu kapılar, topografyanın izin verdiği ölçülerde kulelerle veya sur duvarları ile korunmuştur. Savunma ihtiyacinın ortadan kalkmastyla birlikte, savunma yapılarında özellikle sur kapıları yıkılarak yok olmuştur. Benzer biçimde, Bursa sur kapılarl da yol genişletme çalışmaları nedeniyle yıkılmış, ancak son zamanlarda yapılan çalışmalarla bazı şehir kapıları ihya edilerek ayağa kaldırllmıştır. Bu çalışmada, Bursa Surlarına ait kapıların özellikleri ve korunma yöntemleri araştırılmış ayrıca, iki sur arasına giren Taht-ı Kale Kapısı'nın rekonstrüksiyon yöntemiyle ayă̆a kaldırma çalışmaları anlatılmıştır.

Anahtar Kelimeler: Savunma Mimarisi, Bursa Surları, Şehir Kapıları, Rekonstrüksiyon, Taht-ı Kale Kapısı.

\section{ABSTRACT \\ Bursa City Walls and Gates of the Reconstruction of Taht-I Castle Gate}

Since the early ages people have constructed city walls around settlements for protection. City gates were also built on the city walls to provide access to and departure from a walled city. These gates were protected with towers or city walls in line with the topography of the site. As there was no longer a need for defense,

* Dr. Mimar, Nilüfer, Bursa, hmi6yilmaz@hotmail.com 
structures of defense, especially city gates, were demolished. Likewise, city gates of Bursa were also demolished as a part of road-broadening works. However, some of the city gates have recently been reconstructed. This study sheds a light on characteristics of city gates of Bursa and the related conservation methods and the reconstruction of the Taht-l Castle Gate.

Key Words: Defense architecture, city walls of Bursa, city gates, reconstruction, Taht-l Castle Gate.

\section{BURSA SURLARI VE TARİHÇESI}

Savaş insanlık tarihi kadar, savunma mimarisi de hemen hemen savaş kadar eskidir. İnsanlar yüzlerce yıl boyunca saldırılardan korunmak için önce sur duvarları ve kaleler yapmışlar, daha sonra da içinde güvenle yaşayacakları binaları inşa ederek şehirler kurmuşlardır (Boran 2001; s.8). Bu yüzden, kurulan kent (polis) devletlerin ilk mimarlık ürünleri surlardır. Surlar aynı zamanda kentin sınırlarını da belirlemiştir.

Bursa'nın yaklaşık 2200 yıl önce bir kent devleti (polis) olarak kurulduğu döneme kadar uzanan surlarının yapımına I.Prusias döneminde başlanmıştır (Osmangazi Belediyesi, 2006; s.23). İlk plan kurgusunun ünlü Kartacalı komutan Hannibal tarafindan yapıldığı birçok tarihsel kaynak tarafindan ifade edilen Bursa Surları, İlk ve Ortaçă̆ şehir savunma mimarisinin önemli bir örneğini sergilemektedir. Antik kaynaklara göre; kentin kurucusu Bithynia Kralı I. Prusias'dır (M.Ö.232-192). Kartacalı komutan Hannibal, Roma İmparatorluğu ile yaptığı savaşı kaybedince Prusias'a sığınmıştır. Hanibal burada zafer kazanan bir komutan gibi karşılanıp sayg1 görmüştür. Prusias, Hannibal'dan çok yararlanmış savaşlarda fikirlerinden faydalandığı gibi, şehir kurmakta da onun yaptığı planlara göre hareket etmiştir (Baykal, 1950; s.6). Kent, bizzat Hannibal'in çizdiği plan ve bilgiler 1şığında inşa edilmiştir (Yalman, 2002; s.160). Bursa surlarının takriben M.Ö.185 tarihinde inşa edildiği sanılmaktadır. İç kalenin inşası ise daha öncelere dayanmaktadır (Wilde, 1909; s.2).

Prusia'nın Surları, kentin kurulduğu tepe üstü düzlügün çevresini bir taç gibi, güneydeki ikinci sur ile birlikte yaklaşık $3500 \mathrm{~m}$; lik uzunluğu ile kuşatmaktadır. Surlar, savunmanın güç olmadığı kuzey, doğu ve bat1 yönlerinde yüksek treverten kayaç yamaçları üzerinde tek sur halinde, savunmanın daha güç olduğu güneydeki düzlükte ise, dış sur ve iç sur olmak üzere iki sur halinde inşa edilmiştir. Çift sur, doğu ucundan girilen bir ana kapı ile başlayıp batı ucunda zindan ile sonlanmaktadır. Ayrıca, kenti çevreleyen surların içinde devleti idare eden tekfur ya da sultanların kullandığı sarayın bulunduğu, etrafi yine sur duvarları ve kulelerle çevrili iyi savunulan bir iç kale bulunmaktadır. Savunma mimarisinde, savunmanın en 
yoğun yapıldığı ve en iyi korunan yer "hisar" olarak tanımlanmaktadır (Boran, 2001; s.8). Bu yüzden, İç Kale'yi Bursa'nın hisarı olarak tanımlamak gerekmektedir.

Bursa Kalesi için ilk büyük devrenin Roma istilâsına kadar olan dönem olduğu söylenebilir. Romalılar ve Bizanslılar döneminde sınırlar çok uzakta olduğundan, Bursa Kalesi stratejik anlamda önemini kaybetmiştir. MS 6. yüzyıla doğru İranlılar'ın hücumları ve 7. yüzyılda Arapların işgalleriyle Selçuklulara kadar devam eden devre kalenin ikinci devresidir. Kalenin üçüncü devresi ise, Selçuklular, Haçlılar ve Osmanlılar zamanındaki devredir (Yavaş, 2010; s.110).

Özellikle 11. yüzyılda Selçukluların işgalinden, Osmanlıların kenti ele geçirmesine kadar geçen, yani 13. yüzyıla kadar olan sürede Bursa, Bizans'ın sınır kalesi olarak kalmıştır. Bursa Osmanlılar tarafından 1326 tarihinde alındıktan sonra, surların ilk onarım ve güçlendirme çalışması Orhan bey tarafından yaptırılmıştır. Timur saldırıları ve Karaman oğulları saldırıları sırasında da Çelebi Mehmet tarafından güçlendirilmiştir. $\mathrm{Bu}$ güçlendirmeler sırasında Bizans yapılarına ait bazı malzemeler spolie malzeme olarak kullanılmıştır (Yavaş, 2010; s.111).

İlk yerleşim alanı olması nedeniyle, geçmişten günümüze birçok medeniyete ait izleri görebileceğimiz Bursa, tarih ve kültür yolu üzerinde önemli bir bölge niteliğindedir. Bu yüzden, aradan geçen yaklaşık 2200 yıllık tarihi içinde sur duvarlarının, kulelerin ve şehir kapılarının işlevini koruduğu sürece pek çok değişikliğe ve onarıma uğradığını, bugünkü durumuna bakarak kolayca anlamak mümkündür.

\section{ŞEHIR SUR KAPILARI VE GENEL ÖZELLİKLERİ}

Savunma mimarisinde kapı, en genel anlamıla kullanım amacina uygun olarak sur duvarlarının yüzeyine açılmış birer geçittir. Açılan bu kapılar sayesinde kentin dışına çıkmak, ya da dışarıdan sur duvarları ile korunan kentin içine girmek mümkün olmuştur. Kapılar, sur duvarları ve kuleler kadar stratejik öneme sahiptir. Kapıların, doğru yönlerde ve önemine göre doğru ölçülerde açılması, özellikle ana kapıların tehlikeli girişleri engelleyecek düzeyde teknik donanıma ve korunma özelliklerine sahip olması gerekmekteydi. Bu nedenle, kapı planlamasında ortaya çıkan en önemli problem, kapının kullanım amacına uygun olan yerde tasarlanması ve tasarlanan kapının korunmasının sağlanmasıdır. Bu yüzden, şehir sur kapılarını sur planındaki işlevlerine ve korunma (savunma) yöntemlerine göre iki farklı kategoride değerlendirmek gerekmektedir.

Bu bağlamda, şehir sur kapıları sur planındaki işlevlerine göre 3 ayrı türe ayrılmaktadır. Bunlar, ana kapılar, iç kapılar ve günlük giriş ve çıkışların yapıldığg dar koridorlu kapılardır. $\mathrm{Bu}$ kapıların, kullanım 
amaçlarına ve taşıdıkları öneme göre genişlikleri, yükseklikleri, mimari ve teknik özellikleri farklılıklar göstermektedir.

1- Ana kapılar: Bu kapılar, doğrudan kente ya da iki sur arası gibi iç şehirle bağlantılı şehrin ana bölümlerine giren, aynı zamanda tekerlekli araçların da geçebileceği genişlikte planlanmış yüksek kapılardır. Bu kapılar, diğer kapılara göre daha gösterişli mimari ve teknik özelliklere sahiptir. Genişlikleri, genellikle 3 - 5 m. arasındadır.

2- İç kapılar: Şehrin ana bölümlerini birbirine bağlayan, genellikle ana kapı ile bağlantılı kapılardır. Ana kapıdan girildikten sonra gelen bir iç kap1 vasıtasıyla kentin içine girilmektedir. Bu kapılar, genellikle birden çok sıralı sur duvarlarına sahip savunma yapılarında iç sur beden duvarı üzerinde bulunmaktadır. Bu kapıların açıldığı iki sur arası koridordan şehir dişına çıkan şehir ana kapısı da bulunmaktadır. Bu yüzden, şehir sur ana kapıları gibi, iç kapılarda tekerlekli araç giriş ve çıkışını sağlayacak ölçülerde planlanmıştır. Ayrıca, iç sur duvarı üzerinde, yine iki sur arası koridordan kentin içine bağlanan önü açık huruç kapıları da bulunmaktadır. Huruç kapılarının genişlikleri genellikle 2 m; civarındadır. Bu kapılar aynı zamanda askeri amaçlı da kullanılmıştır. Diğer yandan, iç kalesi bulunan şehirlerde, esas yerleşimden (Şehristan) iç kaleye giren kapının da şehir iç sur kapısı olarak tanımlanması gerekmektedir. Çünkü, bu kapılarda gerek boyut, gerekse mimari ve teknik özellikleriyle ana kapı niteliği taşımaktadır.

3- Günlük giriş ve çıkışların yapıldığı kapılar: Barış zamanlarında şehir dışına, tarlalara, kırlara, ibadet yapılan yerlere günlük olarak bireysel giriş ve çıkışların yapıldığı dar koridorlu kapılardır. Genellikle genişlikleri 11,5 m; olup, koridor üzeri tonoz ile örtülüdür. Bu kapıların dış sur duvar yüzeylerinde açılan örnekleri bulunduğu gibi, daha güvenli giriş ve çıkış1 sağlamak amacıyla kulelerin duvar yüzeylerinde açılan örnekleri de bulunmaktadır. Bu kapılar kulelerin altında açılan koridorun iç ve dış ucunda bulunmaktadır. Dış kapı kulenin dış yüzünde, iç kapı ise genellikle şaşırtmalı L- giriş sağlamak amacıyla, kulenin girişe göre dik açı yapan iç yan yüzlerinde açılmaktadır.

Şehir sur kapıları, topografyanın gerektirdiği şekilde kulelerden ya da sur duvarlarından savunulmaktaydı. Kapının savunulması çok defa 4. Yüzyıldan bu yana L- şeklinde bir plana dayanıyordu. Özellikle yamaçlarda bulunan ana kapılar, sur beden duvarları üzerinden uzun bir hat boyunca savunulurdu. Bu şekilde, kapıya ulaşana kadar düşman, geniş bir platformda sürekli ateş tehdidi altında bulundurulurdu (Kromayer ve Veith 1928; s.42).

A- Kapının savunması sur duvarlarından yapılıyorsa, duvarların plan şeması genellikle aşağıdaki gibi biçimlenmektedir (Akarca, 1987; s.151);

1) Sur duvarları kapının bir yanından, ya da iki yanından dirsek yapmaktadir, 
2) Kapı, V- şeklinde içeri çekilerek kavuşan sur duvarlarının ortasinda yer almaktadir.

3) Birbirini aşacak şekilde, birbiri üzerine bindirilen sur duvarları arasına yerleştirilmektedir.

B- Kapının savunması kuleler vasitasıyla yapılıyorsa ve kapının stratejik önemine göre kuleler aşağıdaki gibi konumlandırılmaktadır (Akarca, 1987; s.151);

1) Kapının her iki yanında kapıya saplanmış vaziyette iki kule bulunmaktadir.

2) Özellikle kapının giriş yüzü esas alındığında, kapının sağ tarafına gelecek biçimde tek kule konumlandırılmaktadır,

3) Kapının girişe göre să̆ yanında konumlandırılan tek kule ile birlikte, içeriden bir iç kule ile kapının iç kısımdan da korunması şeklinde olmaktadir.

Şehir sur kapılarını, korunma biçimlerine göre de genel olarak dört ayrı tipe ayırmak mümkündür (çizim 1). Bunlar (Akarca, 1987; s.149-150);

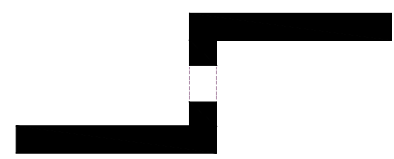

BİNDIRMELİ TIP

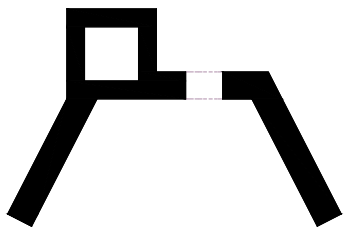

TEK KULELI TIP

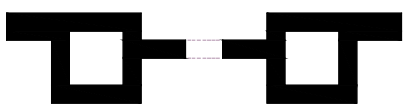

İKİ KULELİ TIPP

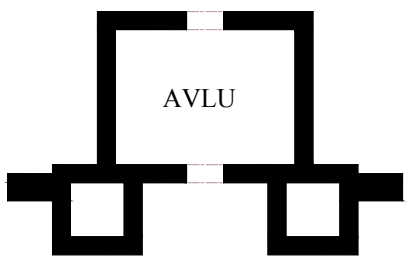

AVLULU TIP

Çizim 1: Korunma biçimlerine göre ana kapı tipleri

- Bindirmeli Tip. Yüzünü kapıya dönmüş düşmanı sağ tarafından vurmaya yönelik, kapıya dirsek yaparak uzayan beden duvarlarının ucunda yer alan ana kapı tipidir.

- İki Kuleli Tip. Kapı, sur duvarlarından ileriye doğru fırlamış iki kulenin ortasında yer almaktadır. Planları gözlük çerçevesine benzemektedir. 
- Tek Kuleli Tip. Kule, kapının girişine göre sağ yanında bulunmaktadır. Kule, doğrudan kapıya saplanır ya da kapıya dirsek yapan beden duvarı üzerinde bulunur.

- Avlulu Tip. İç avlulu ve diş avlulu tip olmak üzere ikiye ayrılır. Bir meydan ya da avlu gerisine alınmış kapılardır. Avlu hem bindirmeli, hem de iki kuleli kapılarda görülür. Bindirmeli kapılarda avlu, sur duvarlarından içeriye ya da dışarıya doğru değişik formlarda çıkıntı yaparak oluşturulmuş koridorlardır. İç avlulu tiplerde genellikle iki kap1 arasında koridor bulunmaktadır. İki kuleli avlularda ise, iki kule arasından avluya girilmektedir. Avlulu tip ana kapılarda düşman avluya girdiği takdirde, onu avlunun dar alanı içinde sıkıştırarak imha etme imkanı bulunmaktadır (Mussche, 1963; s.132).

\section{BURSA SUR KAPILARI}

Bursa şehir sur kapıları ile ilgili incelenen kaynaklarda, Bursa surlarına ait, Saltanat Kap1, Yer Kap1, Fetih Kap1, Kaplıca Kap1 ve Zindan Kapı olmak üzere beş adet ana kapının bulunduğu belirtilmektedir. Ancak, kaynaklarda Bursa sur kapılarının kullanım amaçları, yapısal özellikleri, hangi tür korunma yöntemlerine sahip olduğu ve tipolojileri konusunda yeterli bilgi bulunmamaktadır. Bu yüzden, bugüne kadar Bursa sur kapılarının kullanım özelliklerine ve korunma yöntemlerine göre kategorik değerlendirmeler yapılamamıştır. $\mathrm{Bu}$ durum, özellikle ana kap1 tanımlamalarında ve kapıların günümüzde kullanılan isimlerinde de kargaşa yaşanmasına neden olmuştur.

$\mathrm{Bu}$ amaçla, Bursa surlarının yerinde olmayan kapılarını tespit, belgeleme, analiz, ve ayağa kaldırma çalışmaları kapsamında proje müellifi olarak bu makalenin yazarı tarafından, kapılara (Bursa sur) ait rölöve, restitüsyon ve rekonstrüksiyon proje çalışmaları yapılmıştır. Osmangazi Belediyesi tarafından 2004 yılında başlatılan, halen Bursa Büyükşehir Belediyesi tarafından devam ettirilen çalışmalar sonucu, Bursa surlarına ait kapılar, gerek günümüze ulaşmış kalıntıları, gerekse yerinde yapılan kazılar sonucu ortaya çıkan buluntular ve diğer restitüsyona yönelik elde edilen belgeler değerlendirilerek konumları, nitelikleri, mimari, teknik ve stratejik tüm özellikleri ile belirlenmeye çalışılmıştır. Bu kapsamda, makalenin yazarı tarafindan hazırlanan restitüsyonlara göre yapılan rekonstrüksiyon projeleri ile, günümüzde yerinde olmayan, sırasıyla Saltanat Kapıs1, Yer Kap1 ve en son olarak yapımı 2012 yılında tamamlanan Taht-1 Kale Kapısı aslına uygun olarak inşa edilerek ayağa kaldırılmıştır. Yapılan bu çalışmalarda elde edilen bilgiler değerlendirildiğinde, Bursa surlarına ait kapıların, yukarıdaki bölümlerde genel özellikleri anlatılan diğer sur kapıları ile benzer özellikler taşıdığı görülmüştür. Buna göre, Bursa surlarında ana kapıların bindirme tipe 
sahip uzun sur beden duvarlarıyla ve dıştan tek kule ile korunduğu belirlenmiştir. Şehirden iç kaleye giren kapı haricinde, çift kule ile korunan başka bir kapıya rastlanılmamıştır. Bursa surlarında bulunan kapılar, kullanma amaçlarına ve savunma (korunma) yöntemlerine göre iki ayrı kategoride değerlendirilmiştir. Bursa sur kapıları, sur planındaki konumlarına ve savunma yöntemlerine göre (şekil 1)'de gösterildiği gibi sinıflandırılmıştır.

\section{Kullanım Amaçlarına Göre}

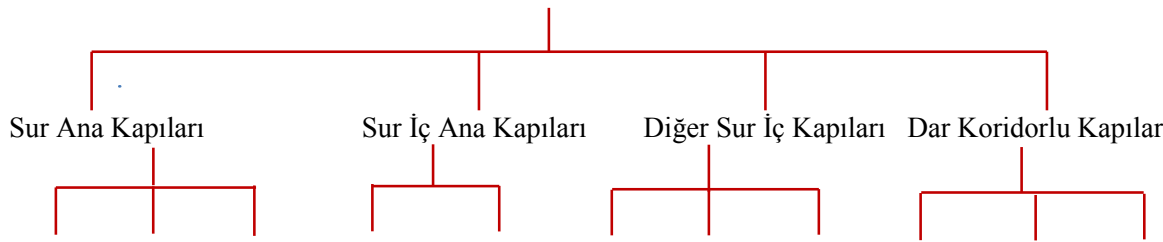

Saltanat Kaplıca Taht-ı Kale Yer Kapı Zindan Kapı Huruç İç Kale Zindan Giriş Yerkapı Pınarbaşı Zindan Kapısı Kapı Kapısı Kapısı Giriş K. Kapısı

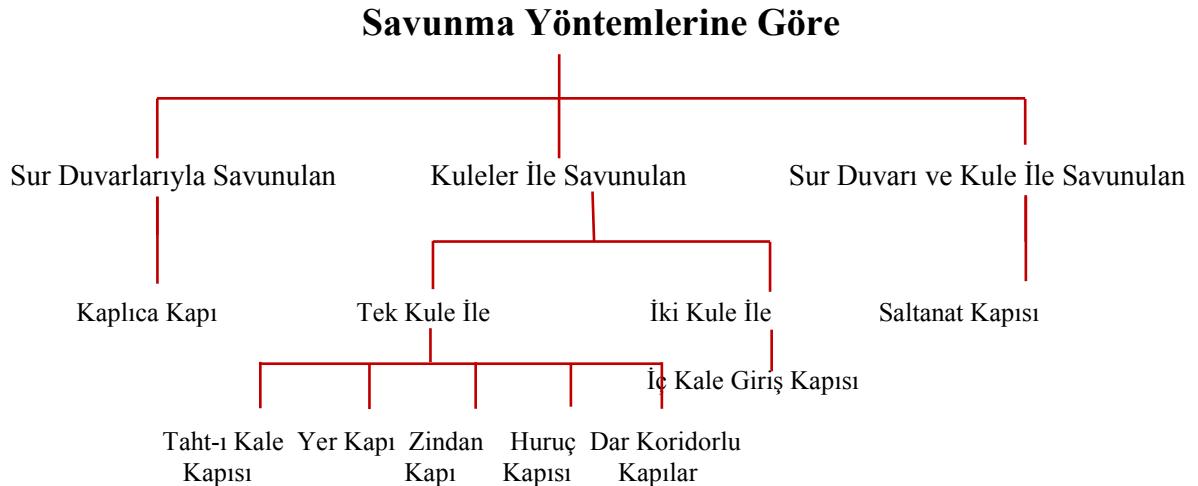

Şekil 1: Kullanım amaçlarına ve savunma yöntemlerine göre Bursa sur Kapılar1

Ayrıca, Bursa şehir sur kapılarının bulunduğu yerler, sur içinde bulunan kente ait restitüsyon planı üzerinde (çizim 2)'de gösterilmiştir. 


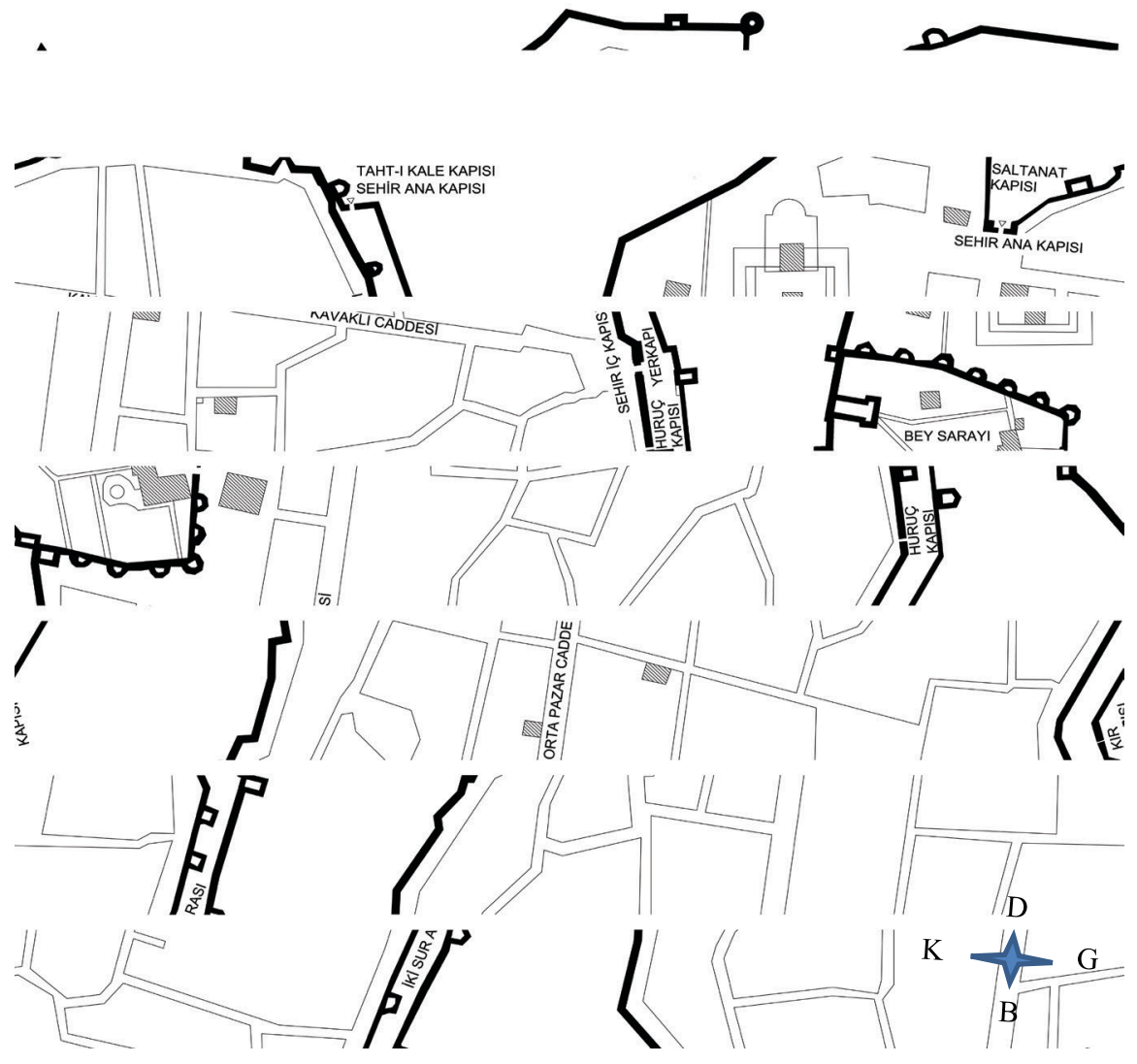

Çizim 2: Bursa sur kapılarının şehir planı restitüsyonu üzerinde yerleri ve tipleri

Bursa sur kapılarının tipleri, özellikleri ve savunma yöntemleri aşağıda anlatılmıştır.

1) Şehir ana sur kapıları: Bursa Surlarında, Saltanat, Kaplıca ve Taht-1 Kale olmak üzere toplam üç adet şehir ana sur kapısı bulunmaktadır. Bunlardan Saltanat Kapısı ve Kaplıca Kapı, sur içinde bulunan kente dışarıdan ve doğrudan giren ana kapılardır. Taht-1 Kale Kapısı ise, doğrudan kent içine açılmamakla beraber, şehrin içine bağlanan kapıları bulunan iki sur arası boşluğa şehir dışından girdiğinden üçüncü ana sur kapısı olarak 
değerlendirilmiştir. Bursa şehir ana sur kapıları, tekerlekli araçların da girip çıkabileceği genişliğe sahip olup, genişlikleri 3-5 m; arasındadır.

Günümüzde kullanılan isimleriyle Bursa Surlarında bulunan şehir sur ana kapiları;

- Saltanat Kapısı: Bursa Surlarına ait 3 şehir ana kapısından birisidir. (şekil 2)'de en solda Saltanat Kapısının, 1850 yilında Clement Le Maitre tarafından çizilmiş gravür resmi, ortada kapının rekonstrüksiyon sonrası bu günkü hali, en sağda ise, kapının ön yüz restitüsyon görünüş çizimi görülmektedir.
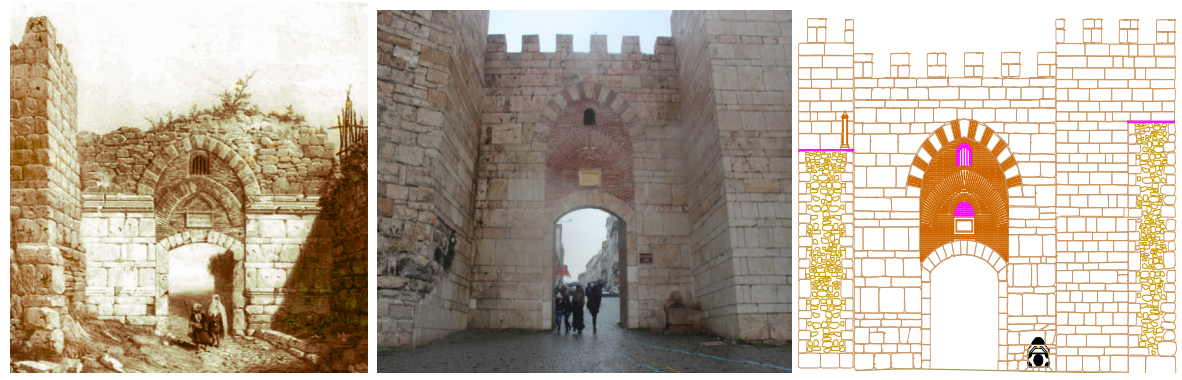

Şekil 2: Saltanat Kapısına ait gravür resmi (1850), günümüz fotoğrafı ve cephe restitüsyon çizimi

$\mathrm{Bu}$ kap1, doğu istikametinden kente doğrudan giren önemli ve diğerlerine göre de en görkemli kapıdır. Bey Sarayı'na çıkan yolun başında bulunduğu için Saltanat Kapısı denilmiştir. Osmanlı döneminde, Kale ve Hisar Kapıs1 olarak da bilinmekteydi (Hammer, 1818). Bu kap1 tekfurların, devlet yöneticilerinin kente giriş ve çıkışta kullandıkları aynı zamanda, gösterişli alayların da gerçekleştirilmesi söz konusu olduğu zaman kullanılan ana kapıdır. Kapı açıklığının her iki yanında bulunan ön yüz duvarları rektogonel pseudo isodomos düzgün kesme taş ile harçsız örülmüş Helenistik dönem örgü tekniğine sahiptir. Taş sıraları, kareye yakın blok taş ve yatay ince taşlardan oluşmuştur. Kapı boşluğunun üzerinde basık taş kemer bulunmaktadır. Kapı açıklığında yukarıya doğru devam eden üst form, seğirdime doğru kalın bir sivri taş-tuğla almaşık kemerle bitmektedir. Arada bulunan tuğla yüz, göz penceresi ile kitabe üzerinde ve tuğla yüzün ortasında bulunan sivri tuğla kemerlerle zenginleştirilmiştir. Ayrıca, tuğla yüz içerisinde girişi ve çıkışı kontrol eden pencereleri de bulunan bir gözetleme odası bulunmaktadır. Gözetleme odası kapıyı koruyan dış kule ile bağlantılıdır.

Saltanat kapıs1, savunma stratejisi yönünden hem sur duvarlaryyla, hem de tek kule ile korunan bindirmeli tipe girmektedir. Girişe göre sağ 
tarafinda dörtgen bir dış kulesi bulunmaktadır. Kapıya saplanan sur beden duvarı, kapının dış yüzüne göre sol tarafından "V" şekliyle gelip, sağ tarafindan kule vasitasiyla dirsek yaparak uzayan bir beden duvarı savunma hattı oluşturmaktadır. Bu hat, bu günkü İl Kültür Müdürlüğü önünden geçmektedir. Bu sayede, hem kapıya doğru ilerleyen düşmanı sürekli ateş altında tutacak uzun bir hat oluşturulmuş, hem de yüzünü kapıya dönen düşmanı sağ tarafından vuracak dar bir avlu alanı yaratılmıştır. Tarihsel süreç içerisinde önemini koruyarak sürdüren kap1, 1855 depreminde zarar gördüğünden, 1904 yılında vilâyet idare meclisinin aldığı bir kararla yıktırılmıştır. Kapının özgün genişliği 3,30 m; iç yüksekliği ise, 4,50 m; dir.

- Kaplıca Kapısı: Batı istikametinden kente doğrudan giren ikinci şehir ana sur kapısıdır. Bursa Kalesinin batıya açılan tek kapısıdır. Bu kapı, Bursa surlarında bindirme tipe sahip L- planlı şemayla korunan tek şehir ana giriş kapısıdır. Kapı, dışarıdan ya da içeriden her hangi bir kule ile korunmamaktadır. Sur beden duvarı, kapının giriş yüzüne göre să̆ yanından dirsek yaparak uzun bir savunma hattı boyunca devam etmektedir. Bu kapının korunması için, dirsek yaparak uzayan sur beden duvarı ile yetinilmesi topografik yapının gerekliliği yanında, düşmanın bu kapıdan kente girebilme ihtimalinin diğer şehir ana kapılarına göre daha düşük olmasından kaynaklanmaktadır. Aşağıda (şekil 3)'de sol tarafta, kapının kente giriş yüzünü gösteren 1827 y1lında Carl Gustav Löwenhielm tarafından çizilmiş gravür resmi (Yenal, 2003; s.179), să̆ tarafta ise, gravüre uygun biçimde hazırlanmış cephe restitüsyon çizimi görülmektedir.
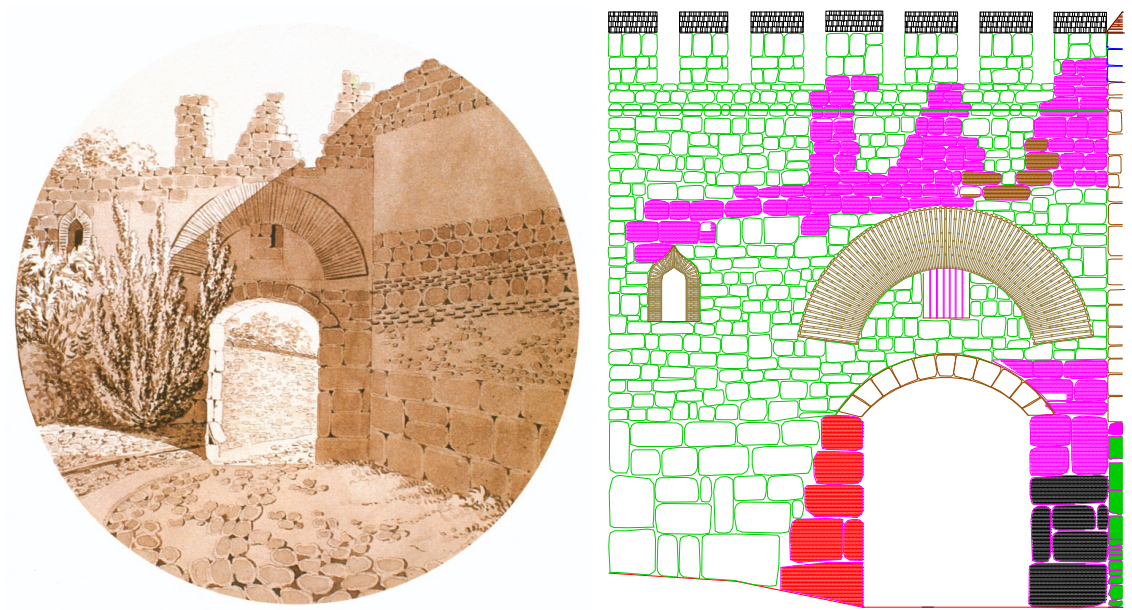

Şekil 3: Kaplıca Kapısına ait gravür resmi (1827) ve cephe restitüsyon çizimi 
- Taht-ı Kale Kapısı: Bursa Surlarının üçüncü şehir ana kapısıdır (resim $1)$.

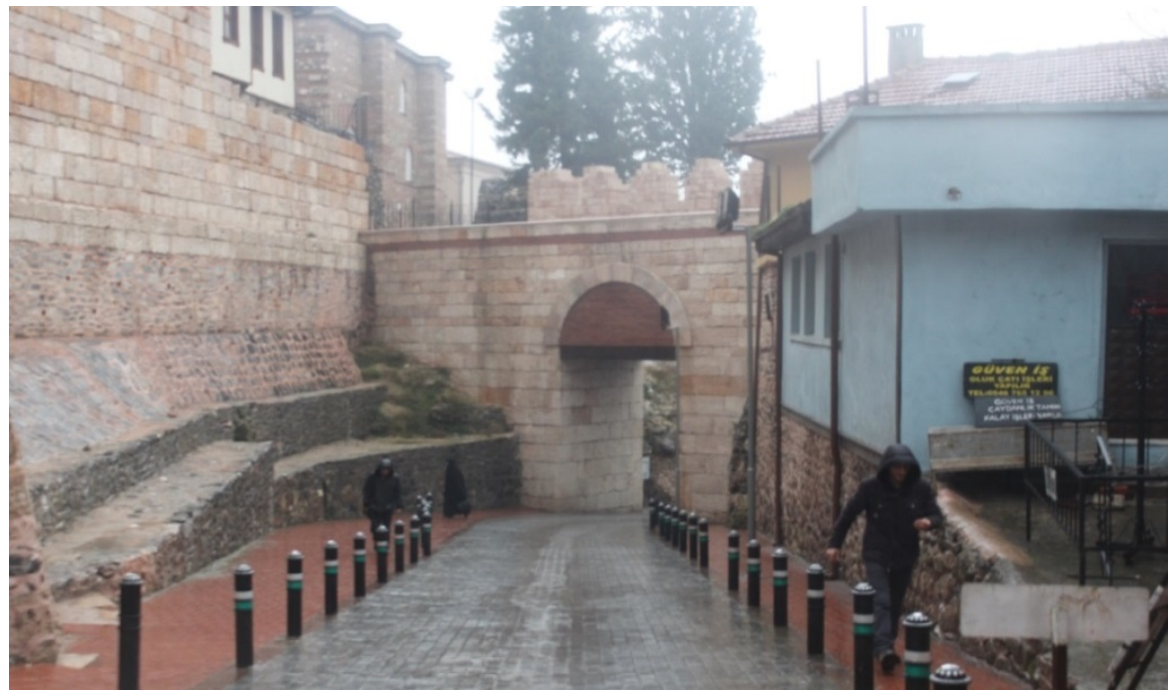

Resim 1: Taht-1 Kale Kapısı iç yüz görünümü

$\mathrm{Bu}$ kap1 doğrudan kente değil, iki sur arası koridora geçit vermektedir. Kap1, mimari özellikleriyle Saltanat ve Kaplıca Kapısına benzememektedir. Diğer kapılarda olduğu gibi, kapı açıklığının üzerinde taş kemer değil, ahşap hatıl bulunmaktadır. Ahşap hatılın üzerinde yükselen tuğla yüz taş kemerle sonlanmaktadır. Giriş boşluğunun üzeri ahşap düz tavandır. Kapının sağ ve sol yanakları düzgün kesim kesme taş örgülüdür. Kapı, dış sur duvarı üzerinden gelen bir servis duvarı ile diş kuleye bağlanmıştır. $\mathrm{Bu}$ ana kapı Osmanlı dönemi öncesi, dışarıdan bir dış kule ile korunurken, Osmanlı döneminde iç sur duvar yüzünde ilave edilen üçgen yüzlü bir iç kule ile içeriden de korunması sağlanmıştır. Kapının genişliği 3,60 m; iç yüksekliği ise, 4,50 m; dir.

2) Şehir sur iç kapıları: Bu kapılar, şehir iç ana sur kapıları ve diğer şehir iç sur kapıları olmak üzere ikiye ayrılmaktadır. Şehir iç ana kapıları, antik şehrin güney tarafında savunmayı güçlendirmek amacıyla yapılan iki sur arası koridordan kente giren, yine tekerlekli araçların da girip çıkabildiği iç sur duvar yüzeyinde açılmış geniş kapılardır. Bu kapılar, şehrin bölümlerini birbirine bağladığından, ayrıca boyutsal, mimari ve teknik özellikleriyle de ana kapı niteliğindedir. Bursa Surlarında, iki sur arasından kente giren iki adet şehir iç ana sur kapısı tespit edilmiştir. Bunlar, Yer Kap1 ve Zindan Kapıdır. Bursa sur kapılanı ile ilgili var olan kaynaklarda belirtildiği gibi, Fetih Kapısı isimli tekerlekli araçların girip çıkabileceği genişlikte bir şehir ana kapısına ya da iki sur arası koridora açılan iç sur 
kapısına rastlanılmamıştır. Su kulesinin bulunduğu Pınarbaşı bölgesinde, sadece günlük giriş ve çıkışların yapılabildiği $1,15 \mathrm{~m}$; genişliğinde bir kır kapısı bulunmaktadır. Kaynaklarda, burada bulunan kır kapıs1 ya da su kulesi şehir ana kapısı olarak belirtilmiştir. Diğer sur iç kapıları ise, şehrin diğer bölümleri olarak kabul edilebilecek iç kale ve zindan boşluğuna giren kapılardır. Bu kapılar şehrin farklı bölümlerini birbirine bağladığından, şehir iç sur kapıları olarak tanımlanması gerekmektedir. kapılar1,

Bursa Surlarının iki sur arasından kente giren şehir iç ana sur

- Yer Kapı (Bab-ı Zemin): Taht-ı Kale isimli şehir ana sur kapısından iki sur arası koridora girildikten sonra yaklaşı $100 \mathrm{~m}$. ileride bulunan, iki sur arası koridordan kente giren ilk şehir iç sur kapısıdır (şekil 4). Şeklin sol tarafında kapının 1890 yılında Sebah\&Joailier tarafından çekilmiş iç yüz fotoğrafı, ortada fotoğrafa göre çizilmiş restitüsyon çizimi, en sağ tarafta ise, kapının rekonstrüksiyon sonrası günümüzdeki hali gösterilmiştir.
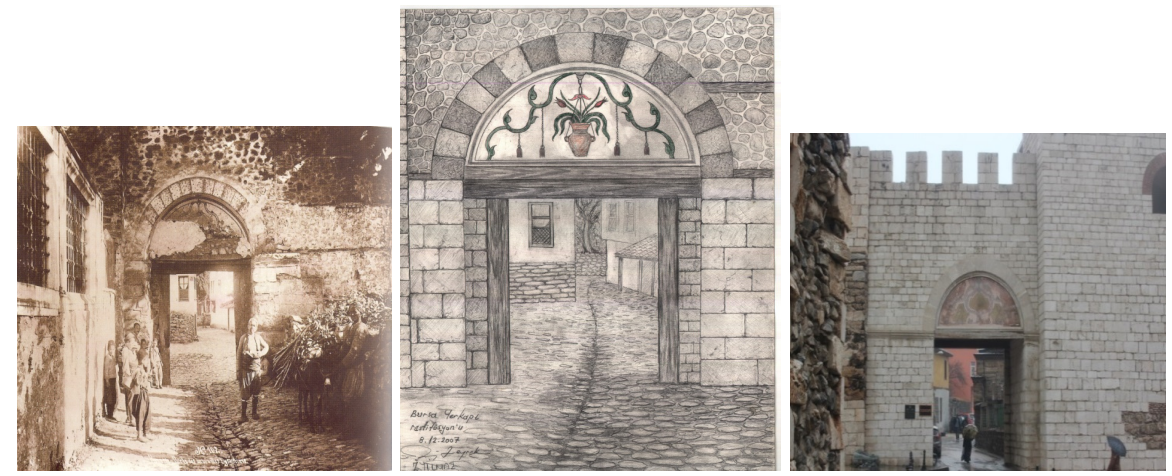

Şekil 4: Yer Kap1 1890 yılına ait fotoğraf, cephe restitüsyonu ve günümüzdeki fotoğrafı

Kapı mimari form yönünden yakınında bulunan Taht-1 Kale kapısına benzemektedir. Kapı açıklığının üzerinde ahşap bir hatıl bulunmaktadır. Ahşap hatılın üzerinde bulunan alının üstü taş bir kemerle tamamlanmaktadır. Kapının iç ve dış yüzeylerinde, ahşap hatıl ile taş kemer arasında bulunan yarım daire formlu alında 19. Yüzyıla ait barok usulü bir süsleme bulunmaktadır. Kapı sağ yanında bulunan dörtgen bir kule ile korunmaktadır. Kapının genişliği 3,60 m; iç yüksekliği ise, 4,50 m; dir.

- Zindan Kapı (Bâb-ı Siccîn): Bu kapı, batı yönüne doğru uzayan iki sur arası koridorun zindan boşluğu ile sonlanan duvarına dik olarak saplanmış iç sur duvar yüzeyinde yer almaktadır. İki sur arasından kente giren ikinci iç sur kapısıdır. Bu kapı da dörtgen genişçe bir kule ile 
korunmaktadır. Kapının mimari formu hakkında herhangi bir bilgi bulunmamaktadır.

3) Günlük giriş ve çıkışların yapıldığı dar koridorlu kapılar: $\mathrm{Bu}$ kapılar, iki sur arası koridordan şehir dışına çıkmak amacıyla dış sur duvarı yüzeyinde açılmış dar bir geçitten ibarettir. Bursa Surlarında bu kapılardan bir tane tespit edilmiş̧ir. Fetih Kapı olarak isimlendirilen bu kapı, Su Kulesinin koruması altında halkın günlük olarak şehir dışına, kırlara, Olmpiyos'a, tarlalara gidip geri döndüğü $1,15 \mathrm{~m}$; genişliğinde dar bir geçittir. Bu kapılardan, Zindan Kapı ile Yer Kapı karşısına denk gelen dış sur duvarı üzerinde de bulunması muhtemeldir. Çünkü, Ortapazar Caddesini dik keserek şehir iç kapılarına doğru gelen tüm yolların aksı, dış sur duvar yüzeyine açılmış bu dar geçitlere çıkmaktadır. Ancak, olması muhtemel diğer iki dar geçit kapıya ait bu güne kadar herhangi bir iz ya da kalıntı bulunamamıştır.

4) Huruç kapıları: Bursa Surlarına ait iki sur arası koridordan kente giren, iç sur duvarı yüzeyinde açılmış üzeri tuğla tonozlu huruç kapıları bulunmaktadır. Bu kapıların genişliği 2,20 m; yüksekliği ise 2,50 m; dir. İç sur duvarı yüzeyine açılmış, aralarında $45 \mathrm{~m}$; mesafe bulunan 2 adet huruç kapısı tespit edilmiştir. Bu kapıların iki sur arası koridor boyunca her $45 \mathrm{~m}$; lik mesafelerde ritmik olarak devam edip etmediği ancak bu alanda yapılacak kamulaştırma, temizlik ve kazı çalışmaları sonucu ortaya çıkacaktır. Mevcut huruç kapılarının her ikisi de dörtgen iç kuleler tarafından korunmaktadır. Bu kapıların askeri amaçlı kullanılmış olması gerekmektedir.

\section{TAHT-I KALE KAPISI REKONSTRÜKSIYONU}

Yukarıda da belirtildiği gibi, Taht-1 Kale Kapısı Bursa Surlarının, şehir dışından iki sur arası bölümüne giren, günümüzde Yokuş Caddesi başlangıcında bulunan şehir ana giriş kapısıdır. Bursa Surlarının üç ana şehir sur kapısından birisi olmasına rağmen günümüze kadar varlığı bilinmemekteydi. Bursa ile ilgili kaynaklarda bu bölgede tek bir kapının var olduğu belirtilmektedir. Özellikle yerli kaynaklarda, iki sur arasından kente giren günümüzde kullanılan ismiyle Kavaklı Caddesi'ne açılan Yer Kapı (Bab-1 Zemin) ana kapı olarak ifade edilmektedir. Oysa, gerek bu bölgede yapılan kazı çalışmaları, gerekse incelenen yabancı kaynaklar, eski dönemlerden günümüze ulaşmış Bursa haritaları ve şehir kapılarına ait eski tarihli fotoğraf ve gravür çizimleri bu kesimde iki ayrı ana kapının bulunduğunu göstermektedir. Walker'a (1870) ait "Brousse; Album Historique" isimli eserde, iki sur arasına giren ve gravür çizimi de bulunan şehir ana sur kapısının adı Yer Kapı olarak belirtilmiştir. Yine, Hammer (1818) "Umblick auf einer Reise von Constantinopel nach Brussa und dem Olympos" isimli eserinde, Bursa surlarına ait 5 ana kap1 ismini sıralarken, 
adı Yer Kapı olarak bilinen diğer kapı ile birlikte iki sur arası koridora giren bu kapının ismini de Yer Kapı olarak belirtmiştir. Görüldüğü gibi, gerek yerli kaynaklarda gerekse yabancı kaynaklarda, birbirine yakın noktalarda bulunan her iki ana kapının ismi, sanki tek bir kapıymış gibi Yer Kapı olarak belirtilmiştir. Bu bağlamda, iki sur arası bölümden kente giren şehir iç ana sur kapısının isminin bilindiği gibi Yer Kapı olarak kalması gerekmektedir. İki sur arasına giren şehir ana sur kapısı ise, onu koruyan diş kulenin hemen altında bulunduğundan Taht-1 Kale Kapısı olarak isimlendirilmiştir.

Bursa sur kapılarını ayağa kaldırma çalışmaları kapsamında, gerek kültür varlığı, gerekse kültürel çevreye olan tarihsel katkısı açısından Taht-1 Kale Kapısının yeniden ihya edilmesinde yarar görülmüştür. Makalenin yazarı tarafından bu maçla yapılan çalışmada, öncelikli olarak kapının yerinin doğru olarak belirlenmesi gerekmektedir. $\mathrm{Bu}$ nedenle, gerçekleştirilen kazı çalışmaları sonucunda, yer altında kapıya ait temel ve duvar kalıntıları elde edilmiştir (Şekil 5). Yer altında elde edilen kalıntılar, aynı noktalarda kapıya ait var olan yerüstü mevcut kalıntılar ile ilişkilendirilmiş ayrıca, kapının yerini gösteren 1862 yılında Suphi Bey tarafından hazırlanmış Bursa haritası (şekil 5), diğer Bursa haritaları ve restitüsyon planları da karşılaştırmalı olarak incelenerek kapının yeri doğru olarak belirlenmiştir.
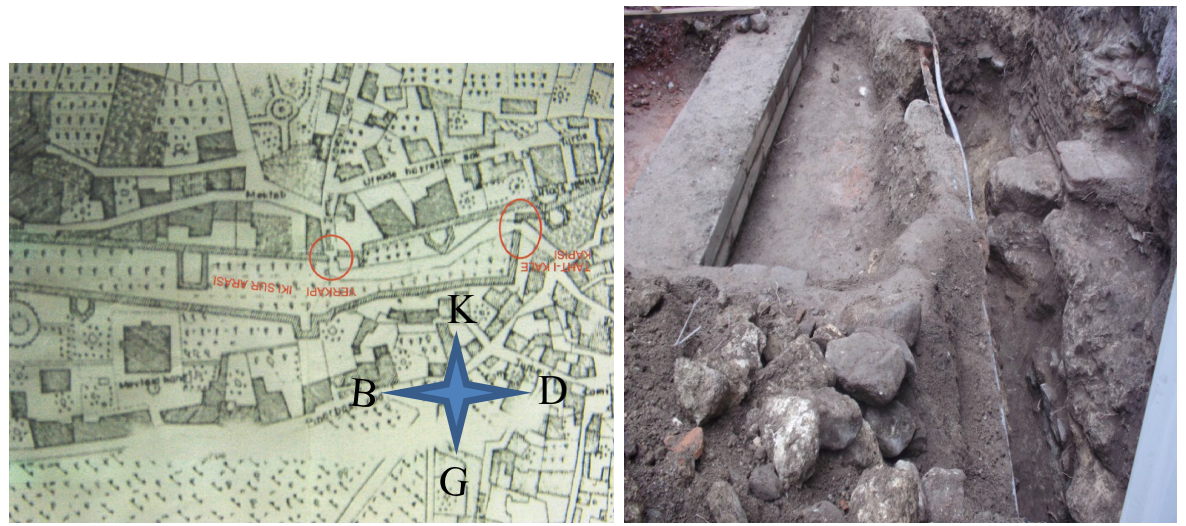

Şekil 5: Suphi Bey Haritasında (1862) Taht-1 Kale Kapısı'nın yeri ve kapıya ait kalıntılar

Ancak, kapının cephesini kapsamlı ve özgün özelliklerine uygun olarak ifade eden, ayakta olduğu zamanları gösteren gravür, fotoğraf gibi görsel içerikli geçerli belgelere ilk zamanlar ulaşılmadığından ilk yapılan restitüsyon çalışmalarında, Bursa Surlarının diğer ana giriş kapıları ile, aynı dönemlerde yapılmış diğer sur yapılarına ait giriş kapı örneklerinin cephe 
özelliklerinden yararlanılmıştır. Fotoğraf ve gravürleri mevcut olan Saltanat kapısı ve Kaplıca kapısı benzer örnekler olarak ele alınmıştır. Buna göre hazırlanan ilk restitüsyon ve rekonstrüksiyon projelerinde, iki sur arasına giren şehir ana giriş kapısının özgün yapısı ve tarihsel kimliğiyle çatışmayacak bir giriş kapısının yapılması planlanmıştır. Önerilerde, diğer şehir ana kapıları gibi, kapı giriş boşluğunun üzerinde basık bir taş kemer, kemer üzerinde tuğla yüz kullanılmıştır. Tuğla yüzün üzeri ise daha geniş tuğla bir sağır kemerle bitirilmiştir. Buna göre hazırlanan rekonstrüksiyon projeleri, Bursa Kültür ve Tabiat Varlıklarını Koruma Yüksek Kurulunun 02.08.2011 tarih ve 7086 sayılı kararı ile onaylanarak yapım çalışmalarına başlanılmıştır. Ancak, kapı imalatı gerçekleştirildikten sonra uygun olan ve görünen bir yerde kapının, gerek Bursa Surlarının diğer şehir ana sur kapıları, gerekse aynı dönemlerde yapılmış benzer şehir ana giriş sur kapıları örnek alınarak hazırlanan rekonstrüksiyon projelerine uygun olarak inşa edildiğini belirten bir yazı konulması önerilmiştir.

Ancak, yapım sürecinde belge araştırmasına devam edilmiştir. Yapılan araştırmalar sonucu elde edilen Walker'e (1870) ait "Brousse Album Historique" isimli eserde, iki sur arasına giren bu şehir ana giriş sur kapısına ait, kapının 1870'li yıllardaki ön yüz konumunu gösteren bir gravür çizimi bulunmuştur (Çalışkan, 2010; s. 235). Elde edilen gravür, kapının Osmanlı dönemindeki durumunu ifade ederken, aynı zamanda bu konuda yeniden hazırlanacak dönemsel restitüsyonların da doğru çizimine azami ölçüde imkan tanımıştır. Aşağıda (şekil 6)'de kapıya ait restitüsyon plan çizimi ile 1870'li yıllarda Mary Walker tarafından çizilmiş kapının giriş yüzünü gösteren gravür çizimi görülmektedir.
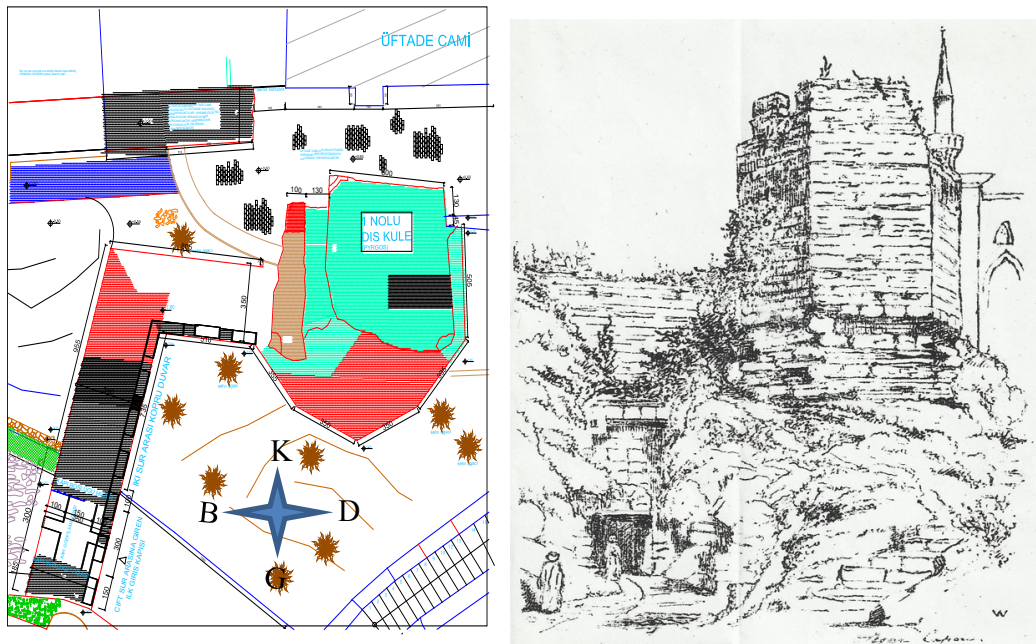

Şekil 6: Taht-1 Kale Kapısı restitüsyon planı ve 1870’li yıllarda çizilmiş gravür resmi 
Gravür çizimlerini ölçekli mimari proje gibi değerlendirmek mümkün değildir. Ancak, yap1 ve çevresi hakkında kapsamlı ve görünür bilgiler içerdiğin den, bu tür verileri restitüsyon çizimlerine olanak sağlayan geçerli belgeler olarak kullanmak mümkündür. Elde edilen gravürün iki sur arasına giren şehir ana kapısı ve çevresi hakkında çizildiği döneme ait önemli bilgiler verdiği muhakkaktır. Gravür çizimi dikkatli biçimde incelendiğinde, resmin sağ üst tarafinda Üftade Camisi ile minaresi, onun önünde iki sur arasına giren ana kapıyı koruyan yüksekçe kayaçların üzerine oturtulmuş dış kule ile, sanki oyularak karşılıklı iki kayaç arasında açılmış iki sur arasına giren ana giriş kapısı görülmektedir.

Gravür çizimine göre incelenen kapının dikdörtgen bir forma sahip olduğu görülmektedir. Kapının sağ ve sol yanaklarında dar taş duvar pazenleri bulunmaktadır. Kapı boşluğu çift sur yönüne doğru derinlemesine bir genişlik arz etmektedir. Kapı boşluğunun üzerinde ahşap bir hatıl bulunmaktadır. Ahşap hatıla oturan alın taş bir kemerle sonlanmaktadır. Kapının üst noktalarına doğru kemerin üzerinde başlayan ve tuğla hatılla tamamlanan ilk iki sırası ince, diğer iki sırası kalın dört sıra kesme taş bloğu bulunmaktadır. Tuğla hatılın üzerinde düzgün kesim bir sıra taş ile, bu sıranın üzerinde de büyük ihtimalle spolien profilli ince yatay taş dizisi görülmektedir. Profilli taş dizisinin üzerinde seğirdime kadar olan kısımda üç sıra, dendanelerin başlangıç noktasına kadar da iki sıra olmak üzere beş sıra taş örgüsü bulunmaktadır. Kapı konstrüksiyonunu oluşturan taş bloklar, rektogonel düzgün kesim pseudo isodomos örgü sistemine sahiptir. Kap1 gravürünün arka fonunda görünen duvar kalıntısı ise, Üftade Cami avlusuna doğru uzayan iç sur duvarının cephe görüntüsüdür. Kapıya ait gravürün oranlanması ve bu oranların kapının yerindeki gerçek konumuna göre değerlendirilmesi sonucu, seğirdime kadar olan toplam yüksekliğin ön cephede yaklaşık, 10,00 m; civarında olduğu tespit edilmiştir.

Kapının özgün cephe özelliklerinin gerek Bizans, gerekse Osmanlı dönemlerinde aynı kaldığı düşünülmektedir. Gravür Osmanlı döneminde çizildiğinden, kapının çevresinde Osmanlı dönemine ait yapılar bulunmaktadır. Bu yapılar, kapıyı dışarıdan koruyan dış kule ile hemen arka tarafinda inşa edilmiş Üftade Cami'sidir. İki sur arasına giren bu ana sur kapısına ait gravür ve yerindeki kalıntılar esas alınarak Osmanlı ve Bizans dönemi olmak üzere iki dönem halinde dönemsel restitüsyon çizimleri hazırlanmıştır. Buna paralel olarak daha önce onaylanan rekonstrüksiyon projesinin, yeniden hazırlanan restitüsyon projelerine uygun olarak tadil edilmesi gerekliliği ortaya çıkmıştır. $\mathrm{Bu}$ amaçla yeniden yapılan rekonstrüksiyon projesinde, kapı genişliği 3,60 m; kapının üst ahşap hatıla kadar yüksekliği 4,50 m; duvar kalınlığı ise, dış sur duvarlarında olduğu gibi 3,00 m; olarak kabul edilmiştir. Yeni duruma göre hazırlanan rekonstrüksiyon tadilat projeleri, Bursa Kültür Varlıklarını Koruma Yüksek 
Kurulunun 26.04.2012 tarih ve 36 sayılı kararı ile onaylanmıştır. Rekonstrüksiyon projesine uygun olarak gerçekleştirilen imalatlarda, kapının özgün malzemesi olan yüzeyi boşluklu Cilimboz trevertenine yakın treverten cinsi taş malzemeler kullanılmıştır (resim 2).

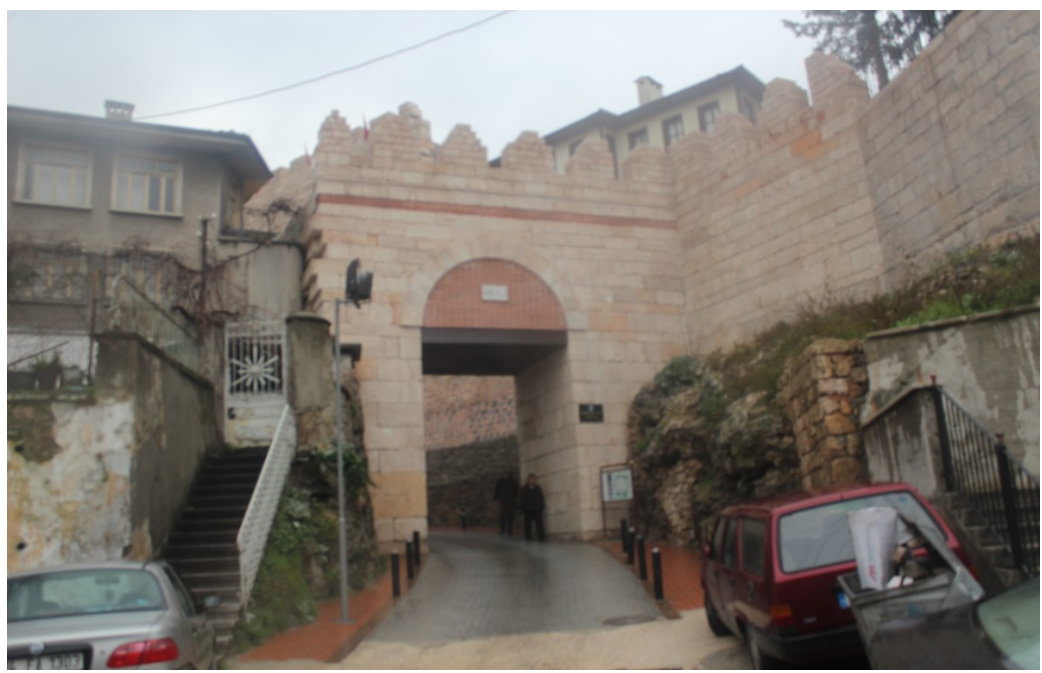

Resim 2: Taht-1 Kale Kapısı dış yüz görünümü

Taşlar, özgününde olduğu gibi, rektogonel pseudo isodomos örgü tekniği ile, önceden analizleri yapılan numune özelliklerine uygun biçimde hazırlanan horasan harç bağlayıcı kullanılarak örülmüştür. Kapı üstü hatıl ile üst taş kemer arasında bulunan alın $4 / 31 / 31 \mathrm{~cm}$; ebatlarında pişmiş toprak tuğla malzeme, her tuğla arası $3 \mathrm{~cm}$; derz bırakılarak horasan harç ile örülmüştür. Taht-1 Kale Kapısının tarihi olma özelliği ve belge değeri yüksek olduğundan gelecek kuşaklara özgün yapım sistemi ile aktarılması hedeflenmiştir. Bu yüzden, yapıtın ayağa kaldırılmasında özgün malzeme ve özgün yapım sistemleri kullanılarak gerçekleştirilen yeniden yapım yöntemi kullanılmıştır.

\section{SONUÇ}

Bursa şehir sur kapıları ile ilgili incelenen tüm yerli kaynaklarda, şehrin beş adet ana sur kapısının var olduğu belirtilmektedir. Bunlar Saltanat Kapıs1, Yer Kap1, Kaplıca Kapıs1, Fetih Kapısı ve Zindan Kapı şeklinde sıralanmıştır. Buradan da anlaşılacağı gibi, Yer Kapı kesiminde 1 adet ana kapının bulunduğu ifade edilmektedir. Bu kap1, iki sur arası bölümden kente giren Bab-1 Zemin ismiyle de bilinen iç sur kapıdır. Yerli kaynaklarda, yine bu kesimde bulunan ve kent dışından iki sur arası bölüme giren diğer ana sur kapısından hiç söz edilmediği görülmektedir. Yabancı bazı kaynaklarda ise, 
iç kapı (Yer Kapı) ile birlikte kent dışından iki sur arası koridora giren bir ana kapının da bulunduğu belirtilmektedir. Ancak, bu kaynaklarda her iki kapının ismi tek bir kapıymış gibi Yer Kapı olarak verilmiştir. Kent dışından kentin iki sur arası bölümüne giren ana kapının varlığı, Bursa sur kapılarının, tespit, belgeleme, analiz ve ayağa kaldırma çalışmaları kapsamında yapılan kazı çalışmaları ve detaylı araştırmalar sonucu elde edilen buluntularla da kanıtlanmıştır. Sözü edilen her iki kapı, bu makalenin yazarı tarafından gerçekleştirilen restitüsyon çalışmaları sonucu hazırlanan rekonstrüksiyon projelerine uygun olarak inşa edilmiş ve ayağa kaldırılmıştır. Görüleceği gibi, iki kapı da gerek boyutsal, mimari ve teknik özellikleriyle, gerekse korunma özellikleri ile ana kapı niteliği taşımaktadır. Bu yüzden, isim yönünden bir kargaşaya meydan vermemek amacıyla, iki sur arası bölümden kente giren şehir sur iç kapısı isminin, günümüzde de bilindiği gibi Yer Kap1 (Bab-1 Zemin) olarak kalmasında, şehir dışından iki sur arası bölüme giren şehir ana sur kapısı isminin ise, onu koruyan kulenin altında kalmasından ve semte de adını vermesinden dolayı Taht-1 Kale Kap1s1 olarak kabul edilmesinde yarar bulunmaktadır.

Diğer yandan, yine yapılan çalışmalar sonucu, kentin dış bölümü olarak tanımlanabilecek iki sur arası koridora açılan Yer Kapı (Bab-1 Zemin) dışında, ana kapı niteliğinde 1 adet daha şehir sur iç kapısının bulunduğu belirlenmiştir. Bu kapı Zindan Kapıdır. Bu iki kapı dışında, iki sur arası koridordan kente giren ana kapı niteliğinde şehir iç kapısı tespit edilememiştir. Bu durum, kaynaklarda belirtildiği gibi, Pınarbaşı kesiminde Fetih Kapı isimli ana kapı özelliği taşıyan bir kapının bulunmadığını göstermektedir. Burada, dış sur duvarı yüzeyine açılmış dar bir geçitten ibaret bir kır kapısı bulunmaktadır. Yine burada kır kapısını ve kente su getiren su yolunu koruyan ve içinde sarnıcı bulunan bir su kulesi bulunmaktadır. Burada bulunan gerek kır kapısının, gerekse bazı yayınlarda ana kap1 olarak belirtilen su kulesinin, ana kap1 özelliği göstermediği muhakkaktır. Pınarbaşı kesiminde yapılacak kazı çalışmaları ve detaylı etüdler sonucu, yeterli veriler elde edilene kadar sembolik ve tarihsel değerleriyle günümüze ulaşmış olan Fetih Kapısı isminin artık bilimsel literatürlerde ana sur kapısı olarak belirtilmemesi gerekmektedir.

Sonuç olarak bu günkü verilerle, Bursa Surlarında beş adet ana kapı özelliği gösteren sur kapısı bulunmaktadır. Bu kapılardan üç adedi kente dışarıdan ve doğrudan giren şehir ana sur kapılarıdır. Bunlar, Saltanat Kapısı, Kaplıca Kapı ve Taht-1 Kale kapısıdır. Diğer iki adet kapı ise, iki sur arası bölümden kente giren Yer Kapı ve Zindan Kapı isimli şehir iç ana sur kapilarıdır.

Ayrıca, Bursa kenti için surların ve sur kapılarının dün savunma amaçlı önemi ne ise, bugün de kentin kültür ve yapı tarihinin anlaşılması açısından önemi aynıdır. Rekonstrüksiyon çalışmaları sonucu ayağa 
kaldırılan Bursa sur kapıları, kentin tarihi silüetinde esaslı bir kaide oluşturarak, tarihi kent imgesini yaratma açısından mekansal ve boyutsal etkileriyle Bursa kimliğinin ayrılmaz birer parçaları haline gelmiştir.

\section{KAYNAKÇA}

Akarca, A. (1987). "Şehir ve Savunması", (2. b.). Türk Tarih Kurumu Yayınları, Ankara.

Baykal, K. (1959). "Bursa ve Anitları”, Aysan Matbaası, Bursa.

Boran, A. (2001). "Anadolu'daki İç Kale Cami ve Mescidleri”, Türk Tarih KurumuYayınları, Ankara.

Çalışkan, N. (2010). "Bursa İle İlgili Osmanlı Dönemi Görsel Belgelerinin Sanat Tarihi Açısından Değerlendirilmesi", Sakarya Üniversitesi Sosyal Bilimler Enstitüsü, Yüksek Lisans Tezi, Sakarya.

Hammer, J. (1818). "Umblick auf einer Reise von Constantinopel nach Brussa und dem Olympos und von da Zurück Über Nicea und Nicomedien", (ss: 98), Pesth.

Kromayer, J., Veith, G. (1928). "Herwesen und Kriegführung der Griechen und Römer", Handbuch der Altertumwissenschaft, Münih.

Mussche, H.F. (1963). "Monumenta Graeca et Romana. Vol.II. Greek Architectura", (fasc.2.) Civil and Military Architecture, Leiden.

Osmangazi Belediyesi. (2006). "Bir İmparatorluğun İzi Osmangazi”, Seçil Ofset, İstanbul.

Walker, M. (1870). "Brousse, Album Historique Constantinople".

Wilde, H. (1909). "Brussa, Eine Entwickelungsstatte Türkischer Architektur in Kleinasien Unter den Ersten Osmanien", Doktora Tezi, Dresden Technischen Hochschule, Verlag von Ernst Wasmuth A-G, Berlin.

Yalman, B. (2002). "Düş Kapı Bursa", (ss: 159-165), Pera Basın Yayın, Bursa.

Yavaş, D. (2010). "Savunma Hatlarından Yaşam Alanlarına Kaleler", (ss: 110-115). Akmat Akınoğlu Matbaacılık, Bursa.

YENAL, Engin (2003), "Bir Zamanlar Türkiye, Carl Gustaf Löwenhielm bir İsveç Elçisi'nin 1820'lerdeki Türkiye Albümü”, Yap1 Kredi Yayınları, İstanbul. 